\title{
Environmental Capabilities and Environmental Innovations of Manufacturing Firms in Malaysia
}

\section{Tze San Ong* (D) | Ah Suat Lee ${ }^{2}$ Boon Heng Teh ${ }^{3}$ | Hussain Bakhsh Magsi ${ }^{4}$ | Sin Huei $\mathrm{Ng}^{5}$}

${ }^{1}$ Universiti Putra Malaysia, Faculty of Economics and Management, Serdang, Selangor, Malaysia ${ }^{2}$ Universiti Tunku Abdul Rahman, Perak, Malaysia

${ }^{3}$ Multimedia University, Selangor, Malaysia

${ }^{4}$ Lasbela University of Agriculture, Water and Marine Sciences, Uthal, Pakistan

${ }^{5}$ Xiamen University, Selangor, Malaysia

* Correspondence to: Tze San Ong, Universiti Putra Malaysia, Faculty of Economics and Management, Department of Accounting and Finance, 43300 Serdang, Selangor, Malaysia. E-mail: tzesan@upm.edu.my

Abstract: The popularity of achieving environmental sustainability among businesses is not exceptional in the green business literature. However, despite its popularity, businesses are still practically clueless about its benefits. This study employs the dynamic capabilities theory to investigate the relationship between environmental capabilities (i.e., environmental strategic focus, shared vision, management support, collaboration, and technological capabilities) and environmental innovation. To test the hypotheses, data from a sample of 124 firms were collected from managers of environmental management system 14001-certified Malaysian manufacturing firms. The collected data were analyzed using structural equation modeling with partial least squares version 3.0. The results indicated that environmental technological capabilities and environmental collaboration both have a positive impact in directly enhancing the firms' environmental innovations. The findings of this study indicate the possibility that manufacturers can remain competitive by integrating environmental considerations at the strategic level; collaborating with suppliers, customers, and the local community for environmental solutions; and investing in environmental technological capabilities.

Keywords: environmental collaboration and technological capabilities, environmental innovation, management support, shared vision, strategic focus.

Article info: Received 29 July 2019 | revised 3 September 2019 | accepted 8 March 2020

Recommended citation: Ong, T. S., Lee, A. S., Teh, B. H., Magsi, H. B., Ng, S. H. (2020). Environmental Capabilities and Environmental Innovations of Manufacturing Firms in Malaysia. Indonesian Journal of Sustainability Accounting and Management, 4(1), 1-12. https://doi.org/10.28992/ijsam.v4i1.248.

\section{INTRODUCTION}

Environmental degradation problems are on the rise in Malaysia. The country's environmental performance index (EPI), a world ranking for environmental evaluation based on high-priority environmental issues, has declined from 51st position in year 2014 to 63rd position in year 2016 (Hsu et al., 2014; Hsu \& Zomer, 2016). Particularly, 
environmental degradation associated with manufacturing activities is a critical issue that needs immediate rectifications. This is due to the fact that manufacturing activities are associated with a substantial volume of pollutions and waste that caused environmental damages (Department of Statistics Malaysia, 2011, 2012).

According to findings of two consecutive annual surveys by the Department of Statistics, Malaysia, based on 7,601 business establishments in Malaysia, manufacturing sector was reported as the largest contributor to environmental expenditure: $80.8 \%$ and $72.2 \%$ for years 2010 and 2011, respectively (Department of Statistics Malaysia, 2011, 2012). Moreover, environmental degradation is further intensified with improper handling of toxic and hazardous waste by manufacturers. For example, the pollution of Semenyih River during year 2016 which caused closure of water treatment plant six times, was a result of illegal discharge of waste effluents into the river by factories nearby (Khalid et al., 2018). Likewise, litigation actions were initiated on Malaysian Vermicelli Manufacturers (Melaka) Sdn Bhd for discharging sewage and waste products into the Melaka River (Mustafa \& Mohamed, 2015). Similarly, there were also cases whereby industrial wastes were burned or dumped into rivers or bushes or just stored in the warehouses (Hassan et al., 2005). The severity of these irresponsible handling of environmental waste is evidenced by increasingly larger penalty imposed by Malaysian courts on cases of environmental pollutions and environmental crimes relating to manufacturing activities (Mustafa \& Mohamed, 2015). These environmental damages caused climate change that has far-reaching damages to the well-being of the world.

Consequently, it is of paramount importance that the manufacturing sector in Malaysia is to be proactive in mitigating environmental damages arising from their manufacturing processes. In fact, according to Muhammad et al. (2015), Malaysian manufacturers are facing intensified demand to green their manufacturing processes as prompted by regulators, customers, non-governmental bodies and society. Environmental implications on the manufacturers are enormous due to the high visibility of environmental damages caused by manufacturing activities. Across the world, manufacturers are subjected to increasing environmental laws and policies from the regulators (Banerjee et al., 2003; Henderson et al., 2017). Likewise, manufacturing firms are compelled to be environmentally responsible as increasingly more consumers and investors become environmentally conscious (Dangelico \& Pujari, 2010). Moreover, manufacturers are also facing intense examinations of their environmental and social performance by those environmental advocacy groups. Consequently, manufacturing firms are obliged to take charge of the negative externalities created by their business activities on all stakeholders including the natural environment (Galbreath, 2011).

Accordingly, environmental issues constitute the major forces shaping business environment that exert profound effect on competitive landscape of manufacturers (Lubin \& Esty, 2010). Indeed, failure to address environmental protection issues may subject these firms to the risks of losing competitiveness (Lubin \& Esty, 2010; Henderson et al., 2017); and may even affect their survival (Kiron et al., 2014), which not only is with regard to Malaysian companies, but also companies worldwide because a proper consideration of capabilities that triggered innovation might enhance competitiveness over time (Stavropoulos et al., 2017).

However, to date, manufacturing businesses are still clueless about what factors could enable concurrent creation of environmental values and economic values. This is evidenced by high failures experienced by firms in gaining superior economic returns from their environmental investments. According to the findings of several global surveys conducted jointly by the Boston Consulting Group and MIT-Sloan Management Review from 2009 to 2013 , there were only approximately $30-37 \%$ of companies surveyed manage to generate superior firm performance from implementing advanced environmental practices (Kiron et al., 2012, 2013, 2014). These surveys further reported increasing failures when firms attempt to justify business case for environmental sustainability (BCES). In particular, a survey by Kiron et al. (2013) based on a world sample of 1,847 corporate leaders indicated that only approximately $35 \%$ of the companies surveyed were able to enhance their profits as a 
result of their sustainability efforts. As such, it appears that businesses worldwide are still struggling to be able to fulfill their environmental accountability and yet be profitable. Moreover, environmental protection investments are expensive, complex, and time consuming in realizing the expected economic benefits (Li et al., 2017), and require effective implementation. Thus, environmental investments are associated with high risks resulting from high possibility of failures. Unsuccessful environmental implementations may possibly lead to large financial losses or firms going out of business due to inability to compete (Kiron et al., 2014).

Furthermore, the possible abandonment of environmental practices by these firms could hinder the potential of solving environmental degradation problems through corporate voluntary environmental accountability. As such, it is highly probable that businesses face difficulty to achieve a BCES, despite empirical evidences from "pays to be green" literature suggested otherwise. Hence, it appears that current literature on "pays to be green" is possibly lacking in informing firms on how to achieve a BCES. Consequently, there is a crucial need to extend the scope of investigation from the focus on "pays to be green" to "what pays to be green," thus enabling discovery of environmental capabilities fundamental in achieving superior firm performance (Dyllick \& Hockerts, 2002; Figge \& Hahn, 2012).

According to the dynamic capabilities view of firm performance (Eisenhardt \& Martin, 2000; Teece, 2007; Kay et al., 2018), all firms need to be equipped with dynamic capabilities to continuously respond to their environmental challenges through reconfiguration of its resources and capabilities that result in maintenance of their competitive capabilities. However, despite investment made in environmental practices, little is known about how dynamic capabilities emerged from proactive environmental practices. Thus, it is important to identify what kind of environmental capabilities could emerge when a firm implements proactive environmental strategies and how these environmental capabilities affect environmental innovation of the firm. Such environmental capabilities can be expected to be the most critical in helping companies to build a BCES (Gabler et al., 2015). As such, this study aims to examine the relationship between environmental capabilities and environmental innovation of Malaysian manufacturing firms.

\section{METHODS}

Data gathering was conducted using questionnaires. Questionnaires were sent to respondents in the targeted firms and follow-up calls to the respective managers were made for improving response rate. A survey package containing: (i) cover letter addressed to the targeted respondent of the sample firms, (ii) questionnaire and (iii) a post-paid self-addressed envelope, was sent to every manager in the targeted sample via postal service. In some circumstances, the questionnaires were sent by fax or e-mail. Multiple telephone calls were made to targeted respondents who had not returned their questionnaire. Replacement questionnaire was provided to those who had missed the previous ones sent to them.

All ISO 14001 Environmental management system (EMS) certified manufacturing firms (483 to date) in Malaysia were selected as population of study. EMS represents advanced environmental practices by manufacturing firms, as its implementation consumes substantial resources of firms. A certified ISO 14001 EMS is not regulatory mandatory for manufacturing firms in Malaysia. However, EMS certification enables a firm to signal to its stakeholders about the quality of its environmental management as well as its commitment in environmental protection. Thus, firms equipped with ISO 14001 EMS reflect a higher level of environmental proactivity with the need to implement proactive environmental strategies.

The questionnaire was first pre-tested by six academic staff and then pilot tested by sending it to 20 companies. The questionnaire was then revised based on the feedback of the respondents. The pilot test is done to improve research design before executing the main field work. This is to ensure that the study runs smoothly 
and to get a qualifying output. A total of 124 survey responses were collected out of 483 questionnaires distributed in June 2018 to all ISO 14001 EMS certified manufacturing firms in Malaysia. The response rate was 25.7\%, which was comparable to other firm-based survey studies in Malaysia (Eltayeb et al., 2011; Lee et al., 2013). Further, the sample size of 124 companies is adequate for structural equation modeling with partial least-squares (SEM-PLS) analysis as it falls within the acceptable range of the sample size (Hair et al., 1998).

Harman's single-factor test was performed on the date in order to examine the possibility of common method bias. Findings indicate that the first factor explains $36.99 \%$ of the total variance. This indicates that the common method bias is not an issue in this study.

An independent $t$-test was conducted across all constructs in order to assess whether data collected are significantly different among early (18 responses) and late (106 responses) respondents. The results reported non-significance of Levene's values, thus risk of non-response bias is non-critical in this study.

\section{RESULTS AND DISCUSSION}

Table 1 shows the profiles of sampled companies. The main activities of these firms include electrical and electronics ( $n=29,23 \%)$, basic metal products, motor vehicles and transport equipment $(n=22,18 \%)$, rubber and plastics $(n=18,15 \%)$, chemicals and chemical products and man-made fibers $(n=16,13 \%)$, and others $(n=39,31 \%)$. Majority of the sampled firms $(n=108,107 \%$ ) have more than $50 \%$ ownership by Malaysian.

Table 1 Company Profiles

\begin{tabular}{|c|c|c|}
\hline Description & Frequency & $\%$ \\
\hline \multicolumn{3}{|l|}{$N=124$} \\
\hline \multicolumn{3}{|l|}{ Companies' main activities } \\
\hline $\begin{array}{l}\text { Electrical machinery, radio television \& communication equipment, } \\
\text { optical equipment }\end{array}$ & 29 & 23 \\
\hline Basic metals and fabricated metal products, motor vehicles and transport equipment & 22 & 18 \\
\hline Rubber and plastics products & 18 & 15 \\
\hline Chemicals, chemical products and man-made fibres & 16 & 13 \\
\hline Others & 39 & 31 \\
\hline \multicolumn{3}{|l|}{ Employees size } \\
\hline Below 200 (small and medium size) & 52 & 42 \\
\hline Between 200 and 500 (large size) & 41 & 33 \\
\hline Above 500 (large size) & 31 & 25 \\
\hline \multicolumn{3}{|l|}{ Company's age (years) } \\
\hline Below 20 & 13 & 11 \\
\hline Between 21 and 40 & 58 & 46 \\
\hline Above 40 & 53 & 43 \\
\hline \multicolumn{3}{|l|}{ Company's ownership } \\
\hline$>50 \%$ Malaysian owned & 108 & 87 \\
\hline$>50 \%$ Foreign owned or joint venture & 16 & 13 \\
\hline
\end{tabular}

Age and size profiles included in Table 1 indicate that majority of the sampled firms are long established with large-scale manufacturing operations. The biggest number of the sampled firms are aged between 21 and 40 years $(n=58,46 \%)$; followed by above 40 years $(n=53,43 \%)$; and the remaining are below 20 years of age $(n=13,11 \%)$. The number of full--time employees indicates the relative size of sampled firms. The majority of the sampled firms are of larger size, employing 200-500 employees $(n=41,33 \%)$, and employing more than 500 
employees $(n=31,25 \%)$. The remaining firms are of smaller size with a workforce below 200 employees $(n=52$, 42\%) (SME Corporation Malaysia).

Table 2 represents the descriptive statistics of measurement items. The results indicate that mean values for all items range from lowest 4.93 to highest 5.19, which confirm the presence of environmental proactivity within the studied companies. All measurement items having kurtosis and skewness (Table 2) within the normality range of -1 to +1 (Hair et al., 2010).

Table 2 Descriptive Statistics

\begin{tabular}{|c|c|c|c|c|c|}
\hline Constructs & Item code & Mean & SD & Kurtosis & Skewness \\
\hline \multirow[t]{7}{*}{ Environmental focus (EF) } & EF1 & 5.07 & 0.77 & $(0.048)$ & 0.189 \\
\hline & $\mathrm{EF} 2$ & 5.02 & 0.81 & 0.370 & 0.327 \\
\hline & EF3 & 5.11 & 0.87 & $(0.246)$ & 0.367 \\
\hline & $\mathrm{EF} 4$ & 4.94 & 0.89 & $(0.550)$ & 0.457 \\
\hline & EF5 & 5.04 & 0.88 & $(0.340)$ & 0.418 \\
\hline & EF6 & 5.03 & 0.83 & $(0.165)$ & 0.364 \\
\hline & EF7 & 5.07 & 0.88 & $(0.386)$ & 0.357 \\
\hline \multirow[t]{4}{*}{ Environmental shared vision (EV) } & EV1 & 5.00 & 0.65 & $(0.591)$ & 0.000 \\
\hline & $\mathrm{EV} 2$ & 5.03 & 0.71 & $(0.608)$ & 0.093 \\
\hline & $\mathrm{EV}_{3}$ & 5.03 & 0.92 & $(0.753)$ & 0.447 \\
\hline & $\mathrm{EV}_{4}$ & 5.07 & 0.84 & $(0.529)$ & 0.372 \\
\hline \multirow[t]{5}{*}{ Environmental collaboration (EC) } & $\mathrm{EC} 1$ & 5.19 & 0.73 & 0.052 & 0.323 \\
\hline & $\mathrm{EC} 2$ & 5.10 & 0.70 & 0.560 & 0.148 \\
\hline & EC3 & 4.93 & 0.73 & 0.489 & 0.615 \\
\hline & $\mathrm{EC} 4$ & 4.98 & 0.92 & $(0.366)$ & 0.678 \\
\hline & EC5 & 5.02 & 0.76 & $(0.373)$ & 0.299 \\
\hline \multirow[t]{6}{*}{ Environmental technological capabilities (ET) } & ET1 & 5.02 & 0.62 & $(0.383)$ & $(0.011)$ \\
\hline & ET2 & 5.03 & 0.70 & (0.109) & 0.248 \\
\hline & ET3 & 5.09 & 0.88 & $(0.048)$ & 0.67 \\
\hline & ET4 & 4.97 & 0.84 & $(0.106)$ & 0.636 \\
\hline & ET5 & 4.94 & 0.84 & 0.035 & 0.695 \\
\hline & ET6 & 5.01 & 0.72 & $(0.726)$ & 0.117 \\
\hline \multirow[t]{8}{*}{ Environmental management supports (EM) } & EM1 & 4.95 & 0.76 & $(0.940)$ & 0.193 \\
\hline & $\mathrm{EM} 2$ & 5.00 & 0.75 & 0.036 & 0.462 \\
\hline & $\mathrm{EM}_{3}$ & 4.94 & 0.86 & $(0.451)$ & 0.580 \\
\hline & EM4 & 4.99 & 0.96 & $(0.369)$ & 0.692 \\
\hline & EM5 & 5.01 & 0.89 & $(0.034)$ & 0.602 \\
\hline & EM6 & 4.96 & 0.77 & $(0.338)$ & 0.505 \\
\hline & EM7 & 4.98 & 0.88 & $(0.482)$ & 0.607 \\
\hline & EM8 & 4.98 & 0.78 & 0.046 & 0.355 \\
\hline \multirow[t]{7}{*}{ Environmental product innovation (ENP) } & ENP1 & 5.05 & 0.68 & $(0.419)$ & 0.093 \\
\hline & ENP2 & 5.15 & 0.71 & 0.686 & 0.599 \\
\hline & ENP3 & 5.02 & 0.83 & 0.255 & 0.733 \\
\hline & ENP4 & 4.98 & 0.93 & $(0.302)$ & 0.721 \\
\hline & ENP5 & 5.03 & 0.88 & $(0.620)$ & 0.441 \\
\hline & ENP6 & 5.05 & 0.74 & 0.056 & 0.408 \\
\hline & ENP7 & 5.07 & 0.73 & $(0.155)$ & 0.283 \\
\hline \multirow[t]{6}{*}{ Environmental process innovation (ENC) } & $\mathrm{ENC}_{1}$ & 4.98 & 0.73 & $(1.117)$ & 0.025 \\
\hline & $\mathrm{ENC2}$ & 4.99 & 0.76 & $(0.005)$ & 0.466 \\
\hline & $\mathrm{ENC}_{3}$ & 4.95 & 0.74 & 0.318 & 0.563 \\
\hline & $\mathrm{ENC}_{4}$ & 4.99 & 0.93 & $(0.354)$ & 0.688 \\
\hline & ENC5 & 4.84 & 0.79 & $(0.989)$ & 0.397 \\
\hline & ENC6 & 4.88 & 0.85 & $(0.860)$ & 0.476 \\
\hline
\end{tabular}


Table 3 shows the factor loadings and reliability of the measurement scales. The factor loadings for all measurement items range from the lowest at 0.700 to the highest at 0.887 . The composite reliability values range from 0.847 to 0.923 . The average variances extracted range from 0.557 to 0.856 . Cronbach's alpha values range from 0.764 to 0.853 .

Table 3 Factor Loadings and Reliability for Constructs

\begin{tabular}{|c|c|c|c|c|c|}
\hline Items & Loadings & Constructs & AVE & $C R$ & CA \\
\hline EF1 & 0.799 & Environmental focused (EF) & 0.557 & 0.862 & 0.802 \\
\hline $\mathrm{EF} 2$ & 0.700 & & & & \\
\hline $\mathrm{EF}_{3}$ & 0.751 & & & & \\
\hline EF6 & 0.713 & & & & \\
\hline EF7 & 0.764 & & & & \\
\hline EV1 & 0.728 & Environmental shared vision (EV) & 0.582 & 0.847 & 0.764 \\
\hline $\mathrm{EV} 2$ & 0.732 & & & & \\
\hline $\mathrm{EV}_{3}$ & 0.791 & & & & \\
\hline $\mathrm{EV}_{4}$ & 0.798 & & & & \\
\hline ET2 & 0.701 & Environmental technological (ET) capabilities (ET) & 0.595 & 0.854 & 0.771 \\
\hline ET4 & 0.730 & & & & \\
\hline ET5 & 0.829 & & & & \\
\hline ET6 & 0.818 & & & & \\
\hline EM1 & 0.839 & Environmental management supports (EM) & 0.568 & 0.887 & 0.847 \\
\hline EM2 & 0.748 & & & & \\
\hline $\mathrm{EM}_{3}$ & 0.723 & & & & \\
\hline EM4 & 0.749 & & & & \\
\hline EM5 & 0.739 & & & & \\
\hline EM8 & 0.719 & & & & \\
\hline EC1 & 0.864 & Environmental collaboration (EC) & 0.772 & 0.911 & 0.853 \\
\hline $\mathrm{EC} 2$ & 0.885 & & & & \\
\hline $\mathrm{EC} 3$ & 0.887 & & & & \\
\hline ENC1 & 0.855 & Environmental innovation (EI) & 0.856 & 0.923 & 0.832 \\
\hline ENC2 & 0.806 & & & & \\
\hline ENC4 & 0.796 & & & & \\
\hline ENC5 & 0.868 & & & & \\
\hline ENC6 & 0.853 & & & & \\
\hline ENP2 & 0.705 & & & & \\
\hline ENP4 & 0.737 & & & & \\
\hline ENP7 & 0.731 & & & & \\
\hline
\end{tabular}

Note: AVE, average variance extracted; CR, composite reliability; CA, Cronbach's alpha

The research question is: "To what extent do environmental capabilities related to environmental innovation?" Therefore, to answer the research question, a hypothesis was established as "Environmental capabilities are positively related to environmental innovation," hypotheses $\mathrm{H}_{1}, \mathrm{H}_{2}, \mathrm{H}_{3}, \mathrm{H}_{4}$ and $\mathrm{H}_{5}$ were developed.

The findings in Table 4 reported that environmental strategic focus has no effects on environmental innovation (standardized beta $=-0.023, p>0.05$ ), andH1 was unsupported. Contrary to the anticipation, the result of this study reveals that environmental strategic focus does not act as a contributing factor toward environmental innovation among environmentally proactive manufacturers. These firms are unlikely to directly gain environmental innovation from their environmental protection priorities when devising strategic planning and implementation, such as corporate goals setting, setting quality criteria to be followed, developing new products, as well as advertising strategies. 
Table 4 Results of Hypothesis Testing

\begin{tabular}{|c|c|c|c|c|c|c|c|}
\hline Hypothesis & Path & Standard beta & Standard error & t value & $\mathrm{p}$ value & Results & $f^{2}$ \\
\hline $\mathrm{H} 1$ & $E F>E N$ & -0.023 & 0.095 & $0.239^{\mathrm{NS}}$ & 0.811 & Unsupported & 0.001 \\
\hline $\mathrm{H}_{2}$ & $\mathrm{EV}>\mathrm{EN}$ & -0.004 & 0.077 & $0.046^{\mathrm{NS}}$ & 0.964 & Unsupported & 0.000 \\
\hline $\mathrm{H}_{3}$ & $\mathrm{ET}>\mathrm{EN}$ & 0.166 & 0.077 & $2.152^{* *}$ & 0.031 & Supported & 0.039 \\
\hline $\mathrm{H}_{4}$ & $\mathrm{EM}>\mathrm{EN}$ & 0.101 & 0.086 & $1.185^{\mathrm{NS}}$ & 0.236 & Unsupported & 0.012 \\
\hline $\mathrm{H}_{5}$ & $E C>E N$ & 0.484 & 0.122 & $3.979^{* * *}$ & 0.000 & Supported & 0.221 \\
\hline
\end{tabular}

Note: NS, non-significant; ${ }^{*} p \leq 0.01, * * * p \leq 0.0001$

The finding of this study reveals manufacturing firms with a higher level of environmental strategic focus do not directly enhance environmental innovation. The reported non-predictive role of environmental strategic focus on environmental innovation fails to provide evidence to validate environmental strategic focus as environmental capabilities among environmentally proactive manufacturers in Malaysia, as underpinned by the dynamic capabilities theory of firm performance (Peteraf, 1993; Teece et al., 1997; Eisenhardt \& Martin, 2000; Helfat \& Peteraf, 2003). Instead, the reported full mediating role of environmental performance provides evidence to validate environmental performance as the environmental capabilities among environmentally proactive manufacturers in Malaysia.

The findings presented in Table 4 reported environmental shared vision has no effects on environmental innovation (standardized beta $=-0.004, p>0.05$ ), and hypothesis $\mathrm{H} 2$ was not supported. Contrary to prediction, the result of this study indicates environmental shared vision does not act as a contributing factor toward environmental innovation among environmentally proactive manufacturers. These firms were unlikely to gain better environmental innovation directly as a result of their efforts in fostering a shared vision on environmental protection among their employees, such as instilling a common environmental goal, an agreement to company's strategic environmental direction, a commitment to environmental strategies of the company; and enthusiasm about environmental mission of the company. The reported insignificant direct relationship between environmental shared vision and environmental innovation was inconsistent with past studies that stress vision plays an antecedent role on environmental innovation performance of a firm (Lawson \& Samson, 2001; Chen et al., 2015).

One possible explanation for the insignificant result could be due to the contextual differences experienced by the sampled firms included in this study. In most cases, firms' organizational work culture affects outcomes of their organizational practices. Malaysian firm work within a collectivist cultural background (Abdullah, 2005), and tend to adopt a transactional leadership with focus more on task efficiency, risk prevention, complying with time limits, and process control oriented (Jogulu, 2010). Hence, the sampled firms tend to exhibit high level of power distance whereby decision-making power is associated with hierarchical authority with emphasis on autocratic leadership (Si \& Wei, 2012), and leaders normally focus on task assessments rather than interaction among employees. Hence, despite of being equipped with a high level of environmental shared vision among employees, however, these firms were not able to achieve improved environmental innovations. This is probably due to a lack of autonomous authority to initiate environmental improvement actions which hinder employees' creativity for improving environmental innovation. Employees' creativity is the pre-requisite for innovation. It involves challenging conventional processes while searching for discoveries of new business processes and/or new product designs.

Taken together, the findings of this study reveal manufacturing firms with a high level of environmental shared vision are not likely gaining superior environmental innovation. The reported non-predictive role of environmental shared vision on environmental innovation fails to provide evidence to validate environmental 
shared vision as environmental capabilities among environmentally proactive manufacturers in Malaysia (Eisenhardt \& Martin, 2000; Helfat \& Peteraf, 2003).

The findings presented in Table 4 provide strong support for $\mathrm{H}_{3}$ (standardized beta $=0.166, p<0.05$ ). As anticipated, firms' environmental innovation is positively predicted by their efforts in creating environmental technological capabilities. This result is consistent with Figueiredo (2002b), which reported technological capabilities as the resource which enables a firm to generate innovations in products, processes, and engineering projects.

This result confirms environmental technological capabilities as contributing factors toward environmental innovation. These firms are more likely to be better in their environmental innovation due to their efforts to identify and respond to environmental technology change, constantly master state-of-the-art environmental technologies, develop environmental technology innovations, and incur a high ratio of sales value on environmental research and development. This is probably due to the fact that manufacturer's environmental capabilities are dependent on the environmental technological capabilities created by them. Firms environmental capabilities could be strengthened as a result of outcome benefits gained from creation of environmental technological capabilities. These outcome benefits include enhancement of absorptive capacity when a firm is able to evaluate and utilize environmental technical knowledge from external sources and integrate them as part of its environmental technologies stocks. The technical knowledge would determine to a large extent the features and design of green products offered by a firm (Afuah, 2002). Further benefits derived from the creation of environmental technological capabilities is a high intensity in technological learning, which enables effective use of technologies, and foster discovery of new ways of applying technical knowledge into production and products design. Moreover, accumulation of technological capabilities is path dependent on technological learning process of a firm (Figueiredo, 2002a, 2002b), which serve as an antecedent of innovation. As such, environmental technological capabilities are crucial to the manufacturing firms as they represent key sources of environmental capabilities for improving environment innovation arising from environmental technology management. Moreover, the path coefficient shows that environmental technological capabilities as the second strongest predictor of environmental innovation among environmentally proactive manufacturing firms in Malaysia.

Accordingly, it is reasonable to conclude that manufacturing firms with a high level of environmental technological capabilities are more likely to achieve superior environmental innovation. In line with the assertion that environmental technologies act as enablers of environmental innovations (Bartlett \& Trifilova, 2010), the reported predictor role of environmental technological capabilities on environmental innovation provides evidence to endorse environmental technological capabilities as environmental capabilities among environmentally proactive manufacturers in Malaysia, as underpinned by the dynamic capabilities theory of firm performance (Eisenhardt \& Martin, 2000; Helfat \& Peteraf, 2003). These environmental capabilities eventually form basis of dynamic capabilities that strengthen firms' competitive capabilities in the form of environmental innovation.

The findings presented in Table 4 reported environmental management supports have no effects on environmental innovation (standardized beta $=0.101, p>0.05$ ), $\mathrm{H}_{4}$ was not supported. Contradicting to prediction; the result of this study indicates environmental management supports do not act as driving factor toward environmental innovation among environmentally proactive manufacturers. These firms are unlikely to gain superior environmental innovation from their environmental management supports adoptions, such as implementing EMS, obtaining ISO 14001 EMS certification, environmental audits, environmental reporting, installing cross functional environmental management team, and life-cycle assessment of products development. The results of this study show the benefits of environmental management supports were not successfully 
converted into anticipated achievements in terms of environmental innovation. This result contradicts with past studies, despite under different perspectives. Earlier studies show EMS was positively associated with eco-innovation (Horbach, 2008; Kesidou \& Demirel, 2012); greening of supplier is positively associated with environmental innovation (Rao, 2002; Chiou et al., 2011); and environmental policy is positively associated with environmentally related innovation activities (Dangelico \& Pujari, 2010; Lanoie et al., 2011).

The findings of this study reveal manufacturing firms with a high level of environmental management supports are not likely gaining superior environmental innovation. The reported non-predictive role of environmental management supports on environmental innovations fails to provide evidence to validate environmental shared vision as environmental capabilities, as underpinned by the dynamic capabilities theory of firm performance (Eisenhardt \& Martin, 2000; Helfat \& Peteraf, 2003).

The findings presented in Table 4 strongly supported this hypothesis (standardized beta $=0.484, p<0.01$ ), thus Hze was supported. In line with prediction, firms' environmental innovation is positively affected by their efforts in securing environmental collaboration. This result was consistent with past empirical studies despite in different perspectives. Moreira \& Silva (2014) reported positive association between cooperation with customers and marketing innovation. Others reported positive associations between customer engagement and innovation (Witell et al., 2011; Moreira \& Silva, 2014).

The result of this study endorses environmental collaboration as a predictor of environmental innovation. The manufacturers are more likely to be better in their environmental innovation as a result of involving suppliers, customers and the local communities in their environmental management activities. This is probably due to their environmental capabilities that could be strengthened as a result of outcomes gained from environmental collaboration. These benefits include access to market information embedded within customers' experiences (Prahalad \& Ramaswamy, 2003; Moreira \& Silva, 2014), and access to pool of environmental knowledge and skills embedded across the supply chain (Vachon \& Klassen, 2008), which facilitates green product and green process development. As such, environmental collaboration with suppliers, customers and the local communities is highly important to the manufacturing firms as it represents dominant sources of environmental capabilities for improving environmental innovation arising from collaborating with partners along supply chain. Moreover, the large path coefficient shows that environmental collaboration has a strongest driver effect on environmental innovation among environmentally proactive manufacturing firms in Malaysia.

In sum, this study reveals that manufacturing firms with high level of environmental collaboration are more likely to achieve superior environmental innovation. The reported positive role of environmental collaboration on environmental innovation provides evidence to validate environmental collaboration as environmental capabilities among environmentally proactive manufacturers in Malaysia, as underpinned by the dynamic capabilities theory of firm performance (Eisenhardt \& Martin, 2000; Helfat \& Peteraf, 2003). These environmental capabilities eventually form the basis of dynamic capabilities that strengthen firms' competitive capabilities in the form of environmental innovation.

\section{CONCLUSION}

Further, the study proposes and empirically examined the antecedents of environmental competitive capabilities. Current literature has mainly focused on evaluating effects of environmental competitive capabilities on economic performance. This research study articulated the concept of environmental capabilities, and posit them as sources of dynamic capabilities which helps firms to maintain its ability to compete. The findings reveals environmental strategic focus, environmental collaboration and environmental technological capabilities serve 
as environmental capabilities as they enhance environmental innovation. The findings of this study suggest possibility for manufacturers to remain competitive via integrating environmental consideration at strategic level, collaborates with suppliers, customers and the local community for environmental solutions, and invest in environmental technological capabilities. This is highly probable as long as the benefits of environmental strategic focus, environmental collaboration and environmental technological capabilities are being converted into environmental innovation. Government policies tailored at strengthening overall technologies infrastructure at industry and country level are needed in order to enable firms to realize superior environmental performance from technology factor. For example, the National Green Technology Policy enforced in year 2009 provides incentives for green technologies adoptions; and financing assistance is established via Green Technology Financing Scheme (Bakar et al., 2011). Such measures should be continued and enhanced in order to enable manufacturers to realize radically improved environmental performance and environmental innovations from technology factor.

\section{ORCID}

Tze San Ong (1D) http://orcid.org/0000-0001-7756-9404

\section{REFERENCES}

Abdullah, A. (2005). Cultural Dimensions of Anglos, Australians and Malaysians. Journal of International Business and Entrepreneurship, 2(2), 21-33.

Afuah, A. (2002). Mapping Technological Capabilities into Product Markets and Competitive Advantage: The Case of Cholesterol Drugs. Strategic Management Journal, 23(2), 171-179, https://doi.org/10.1002/smj.221.

Bakar, K. A., Sam, M. F. M., Tahir, M. N. H., Rajiani, I., \& Muslan, N. (2011). Green Technology Compliance in Malaysia for Sustainable Business Development. Journal of Global Management, 2(1), 55-65.

Banerjee, S. B., Iyer, E. S., \& Kashyap, R. K. (2003). Corporate Environmentalism: Antecedents and Influence of Industry Type. Journal of Marketing, 67(2), 106-122, https://doi.org/10.1509/jmkg.67.2.106.18604.

Bartlett, D., \& Trifilova, A. (2010). Green Technology and Eco-Innovation: Seven Case-Studies from a Russian Manufacturing Context. Journal of Manufacturing Technology Management, 21(8), 910-929, https://doi.org/ 10.1108/17410381011086757.

Chen, Y. S., Chang, C.-H., Yeh, S.-L., \& Cheng, H. I. (2015). Green Shared Vision and Green Creativity: The Mediation Roles of Green Mindfulness and Green Self-Efficacy. Quality \& Quantity, 49(5), 1169-1184, https://doi.org/10.1007/s11135-014-0041-8.

Chiou, T.-Y., Chan, H. K., Lettice, F., \& Chung, S. H. (2011). The Influence of Greening the Suppliers and Green Innovation on Environmental Performance and Competitive Advantage in Taiwan. Transportation Research Part E: Logistics and Transportation Review, 47(6), 822-836, https://doi.org/10.1016/j.tre.2011.05. 016.

Dangelico, R. M., \& Pujari, D. (2010). Mainstreaming Green Product Innovation: Why and How Companies Integrate Environmental Sustainability. Journal of Business Ethics, 95(3), 471-486, https://doi.org/10.1007/ s10551-010-0434-0.

Department of Statistics Malaysia. (2011). Economic Census: Environmental Compliance. Putrajaya: Government of Malaysia.

Department of Statistics Malaysia. (2012). Report on the Survey of Environmental Protection Expenditure. Putrajaya, Malaysia: Government of Malaysia.

Dyllick, T., \& Hockerts, K. (2002). Beyond the Business Case for Corporate Sustainability. Business Strategy and the Environment, 11(2). https://doi.org/10.1002/bse.323 
Eisenhardt, K. M., \& Martin, J. A. (2000). Dynamic Capabilities: What Are They? Strategic Management Journal, 21 (10-11), 1105-1121, https://doi.org/10.1002/1097-0266(200010/11).

Eltayeb, T. K., Zailani, S., \& Ramayah, T. (2011). Green Supply Chain Initiatives Among Certified Companies in Malaysia and Environmental Sustainability: Investigating the Outcomes. Resources, Conservation and Recycling, 55(5), 495-506, https://doi.org/10.1016/j.resconrec.2010.09.003.

Figge, F., \& Hahn, T. (2012). Is Green and Profitable Sustainable? Assessing the Trade-Off between Economic and Environmental Aspects Environmental Performance. International Journal of Production Economics, 140(1), 92-102, https://doi.org/10.1016/j.jpe.2012.02.001.

Figueiredo, P. N. (2002a). Does Technological Learning Pay Off? Inter-Firm Differences in Technological Capability-Accumulation Paths and Operational Performance Improvement. Research Policy, 31(1), 73-94, https://doi.org/10.1016/S0048-7333(01)00106-8.

Figueiredo, P. N. (2002b). Learning Processes Features and Technological Capability-Accumulation: Explaining Inter-Firm Differences. Technovation, 22(11), 685-698, https://doi.org/10.1016/S0166-4972(01)00068-2.

Gabler, C. B., Richey, R. G., \& Rapp, A. (2015). Developing an Eco-Capability Through Environmental Orientation and Organizational Innovativeness. Industrial Marketing Management, 45(2), 151-161, https://doi.org/10. 1016/j.indmarman.2015.02.014.

Galbreath, J. (2011). Sustainable Development in Business: A Strategic View. In S. O. Idowu, \& C. Louche (Eds.), Theory and Practice of Corporate Social Responsibility (pp. 89-105). Berlin, Heidelberg: Springer, https://doi.org/10.1007/978-3-642-16461-3_6.

Hair, J. F., Jr., Black, W. C., Babin, B. J., \& Anderson, R. E. (1998). Multivariate Data Analysis with Readings. Englewood Cliffs, NJ: Prentice-Hall.

Hair, J. F., Black, W. C., Babin, B. J., \& Anderson, R. E. (2010). Multivariate Data Analysis (7th ed.). Upper Saddle River: Prentice-Hall.

Hassan, M. N., Afroz, R., Mohamed, A. F., \& Awang, M. (2005). Economic Instruments for Managing Industrial Waste in Malaysia. Malaysian Journal of Environmental Management, 6(2), 87-106.

Helfat, C. E., \& Peteraf, M. A. (2003). The Dynamic Resource-Based View: Capability Lifecycles. Strategic Management Journal, 24(10), 997-1010, https://doi.org/10.1002/smj.332.

Henderson, R., Reinert, S. A., Dekhtyar, P., \& Migdal, A. (2017). Climate Change in 2017: Implications for Business. Harvard Business School, 14.

Horbach, J. (2008). Determinants of Environmental Innovation - New Evidence from German Panel Data Sources. Research Policy, 37(1), 163-173, https://doi.org/10.1016/j.respol.2007.08.006.

Hsu, A., Emerson, J., Levy, A., Johnson, L., Malik, O., Schwartz, J., \& Jaiteh, M. (2014). The 2014 Environmental Performance Index. New Haven, USA: Yale Center for Environmental Law \& Policy, Yale University.

Hsu, A., \& Zomer, A. (2016). Environmental Performance Index. Wiley StatsRef: Statistics reference online, 1-5, https://doi.org/10.1002/9781118445112.stat03789.pub2.

Jogulu, U. D. (2010). Culturally-Linked Leadership Styles. Leadership \& Organization Development Journal, 31(8), 705-719, https://doi.org/10.1108/01437731011094766.

Kay, N. M., Leih, S., \& Teece, D. J. (2018). The Role of Emergence in Dynamic Capabilities: A Restatement of the Framework and Some Possibilities for Future Research. Industrial and Corporate Change, 27(4), 623-638, https://doi.org/10.1093/icc/dty015.

Kesidou, E., \& Demirel, P. (2012). On the Drivers of Eco-Innovations: Empirical Evidence from the UK. Research Policy, 41(5), 862-870, https://doi.org/10.1016/j.respol.2012.01.005.

Khalid, R. M., Mokhtar, M. B., Jalil, F., Ab Rahman, S., \& Spray, C. (2018). Legal Framing for Achieving 'Cood Ecological Status' for Malaysian Rivers: Are There Lessons to be Learned from the EU Water Framework Directive? Ecosystem Services, 29, 251-259, https://doi.org/10.1016/j.ecoser.2017.06.015.

Kiron, D., Kruschwitz, N., Haanaes, K., Reeves, M., \& Goh, E. (2013). The Innovation Bottom Line. MIT Sloan Management Review, 54(3).

Kiron, D., Kruschwitz, N., Haanaes, K., \& Velken, I. V. S. (2012). Sustainability Nears a Tipping Point. MIT Sloan Management Review, 53(2), 69-74. 
Kiron, D., Kruschwitz, N., Rubel, H., Reeves, M., \& Fuisz-Kehrbach, S.-K. (2014). Sustainability's Next Frontier. MIT Sloan Management Review, 55(2), 1-25.

Lanoie, P., Laurent-Lucchetti, J., Johnstone, N., \& Ambec, S. (2011). Environmental Policy, Innovation and Performance: New Insights on the Porter Hypothesis. Journal of Economics \& Management Strategy, 20(3), 803-842, https://doi.org/10.1111/j.1530-9134.2011.00301.x.

Lawson, B., \& Samson, D. (2001). Developing Innovation Capability in Organisations: A Dynamic Capabilities Approach. International Journal of Innovation Management, 5(3), 377-400, https://doi.org/10.1142/ S1363919601000427.

Lee, V.-H., Ooi, K.-B., Chong, A. Y.-L., \& Lin, B. (2013). A Structural Analysis of Greening the Supplier, Environmental Performance and Competitive Advantage. Production Planning \& Control: The Management of Operations, 26(2), 116-130, https://doi.org/10.1080/09537287.2013.859324.

Li, S., Ngniatedema, T., \& Chen, F. (2017). Understanding the Impact of Green Initiatives and Green Performance on Financial Performance in the US. Business Strategy \& the Environment, 26(6), 776-790. https://doi.org/10.1002/bse

Lubin, D. A., \& Esty, D. C. (2010). The Sustainability Imperative. Harvard Business Review, 88(5), 42-50.

Moreira, J., \& Silva, M. J. A. M. (2014). Cooperation between the Consumer and Firms as a Determinant of Marketing Innovation: Empirical Study of Portuguese Firms. Contemporary Management Research, 10(3), 215-232, https://doi.org/10.7903/cmr.12370.

Muhammad, I. Q., Amran, M. R., Ahmad, J., \& Tan, O. K. (2015). Sustainability: A New Manufacturing Paradigm. Jurnal Teknologi, 77(22), 52-89, https://doi.org/10.11113/jt.v77.6661.

Mustafa, M., \& Mohamed, N. S. (2015). The Development of Environmental Crime and Saction in Malaysia. European Scientic Journal, 11(25), 29-39.

Peteraf, M. A. (1993). The Cornerstones of Competitive Advantage: A Resource-Based View. Strategic Management Journal, 14(3), 179-191, https://doi.org/10.1002/smj.4250140303.

Prahalad, C. K., \& Ramaswamy, V. (2003). The New Frontier of Experience Innovation. MIT Sloan Management Review, 44(4), 12-18.

Rao, P. (2002). Greening the Supply Chain: A New Initiative in South East Asia. International Journal of Operations \& Production Management, 22(6), 632-655, https://doi.org/10.1108/01443570210427668.

Si, S., \& Wei, F. (2012). Transformational and Transactional Leaderships, Empowerment Climate, and Innovation Performance: A Multilevel Analysis in the Chinese Context. European Journal of Work and Organizational Psychology, 21(2), 299-320, https://doi.org/10.1080/1359432X.2011.570445.

Stavropoulos, S., Wall, R., \& Xu, Y. (2017). Environmental Regulations and Industrial Competitiveness: Evidence from China. Applied Economics, 50(12), 1378-1394. https://doi.org/10.1080/00036846.2017. 1363858.

Teece, D. J. (2007). Explicating Dynamic Capabilities: The Nature and Microfoundations of (Sustainable) Enterprise Performance. Strategic Management Journal, 28(13), 1319-1350, https://doi.org/10.1002/smj.640.

Teece, D. J., Pisano, G., \& Shuen, A. (1997). Dynamic Capabilities and Strategic Management. Strategic Management Journal, 18(7), 509-533, https://doi.org/10.1002/(SICl)1097-0266(199708).

Vachon, S., \& Klassen, R. D. (2008). Environmental Management and Manufacturing Performance: The Role of Collaboration in the Supply Chain. International Journal of Production Economics, 111(2), 299-315, https://doi.org/10.1016/j.ijpe.2006.11.030.

Witell, L., Kristensson, P., Gustafsson, A., \& Löfgren, M. (2011). Idea Generation: Customer Co-Creation Versus Traditional Market Research Techniques. Journal of Service Management, 22(2), 140-159, https://doi.org/ 10.1108/09564231111124190. 